\begin{tabular}{|l|c|c|c|r|}
\hline $\begin{array}{l}\text { Cuadernos de Investigación Geográfica } \\
\text { Geographical Research Letters }\end{array}$ & 2017 & N $^{\circ} 43(1)$ & pp. 83-100 & $\begin{array}{r}\text { ISSN 0211-6820 } \\
\text { eISSN 1697-9540 }\end{array}$ \\
\hline
\end{tabular}

DOI: http://doi.org/10.18172/cig.3211

(C) Universidad de La Rioja

\title{
MASS SOIL MOVEMENT ON TERRACED LANDSCAPES OF THE MEDITERRANEAN MOUNTAIN AREAS: A CASE STUDY IN THE IBERIAN RANGE, SPAIN
}

\author{
J. ARNÁEZ1* ${ }^{*}$ N. LANA-RENAULT ${ }^{1}$, P. RUIZ-FLAÑ̃ ${ }^{1}$, \\ N. PASCUAL ${ }^{1}$, T. LASANTA ${ }^{2}$ \\ 'Área de Geografía Física, Departamento de Ciencias Humanas, Universidad de La Rioja, \\ Edificio Luis Vives, 26004 Logroño, Spain. \\ ${ }^{2}$ Instituto Pirenaico de Ecología, CSIC, Campus de Aula Dei, Apdo. Correos 13034, 50080 Zaragoza, Spain.
}

\begin{abstract}
Terraces represent one of the most common agricultural landscapes in Mediterranean mountainous regions. However, the demographic and socioeconomic changes occurring in the second half of the last century caused terraces abandonment, leading to the loss of maintenance work required by these agricultural structures, and promoting various erosion processes, in particular the collapse of stone walls and small slides in risers. This paper analyses these mass movements by quantifying their size and frequency and defining the variables involved in their triggering in the upper valleys of Leza, Jubera and Cidacos rivers (Camero Viejo, Iberian Range, Spain), where bench terraces occupied 13,274 hectares (63\% of agricultural space). A total amount of 240 small slides were recorded in 53 terraces studied, which means an average of 4.5 slides per plot and $33.1 \mathrm{~m}^{3}$ of material mobilized per $100 \mathrm{~m}$ of wall. This study proves that the most decisive causes for slides to start are related to soil infiltration capacity, as well as to the way in which water runs down the hillside.
\end{abstract}

Movimientos en masa en paisajes con terrazas de la montaña mediterránea: un caso de estudio en el Sistema Ibérico (España)

RESUMEN. Los bancales configuran uno de los paisajes agrarios más característicos de las regiones de montaña mediterránea. Sin embargo, cambios demográficos y socioeconómicos, ocurridos en la segunda mitad del siglo pasado, provocaron el abandono de las terrazas, con la consecuente desaparición de las labores de mantenimiento que requerían estas estructuras agrarias. Esto favoreció la activación de diversos procesos de erosión entre los que destacan el colapso de los muros de piedra y los pequeños desprendimientos que se activan en los saltos de las terrazas. En este trabajo se analizan estos movimientos en masa cuantificando sus dimensiones y frecuencia, y definiendo las variables que intervienen en su desencadenamiento en los altos valles del Leza, Jubera y Cidacos (Camero Viejo, Sistema Ibérico, España), donde los bancales llegaron a ocupar 13.274 hectáreas, 
es decir el $63 \%$ del espacio agrícola. Un total de 240 desprendimientos fueron contabilizados en las 53 terrazas analizadas, lo que supone un número medio de 4,5 desprendimientos por parcela y 33,1 $\mathrm{m}^{3}$ de material movilizado por $100 \mathrm{~m}$ de muro. En el estudio se comprueba que las causas más decisivas para la iniciación de desprendimientos están vinculadas a la capacidad de infiltración de los suelos y a la forma en que el agua circula por la ladera.

Key words: mass movements, agricultural terraces, land abandonment, infiltration, Mediterranean mountains, Spain.

Palabras clave: movimientos en masa, bancales, abandono de tierras, infiltración, montaña mediterránea, España.

* Corresponding author: José Arnáez, Área de Geografía Física, Departamento de Ciencias Humanas, Universidad de La Rioja, Edificio Luis Vives, C/ Luis de Ulloa, 26004 Logroño, Spain. E-mail: jose.arnaez@unirioja.es

\section{Introduction}

Historically, agricultural spaces in mountainous areas have adapted to rigorous environmental conditions from both a climatic and topographical point of view (Price, 1981). Adapting agricultural plots to the severe gradient of the slopes was achieved by designing sloping and terraced fields within the framework of a subsistence economy and insignificant trade flows. Thus, the extent of agricultural surface was important in some mountainous regions, especially in the Mediterranean area (Lasanta, 1990; Lasanta et al., 2017).

Agricultural land abandonment during the $20^{\text {th }}$ century occurred mainly in the less productive mountainous regions and resulted in loss of landscape heterogeneity and facilitated the disappearance of a cultural landscape built over centuries (Lasanta et al. 2013). At the same time, the lack of maintenance of these fields, in addition to other factors, activated new hydrological and geomorphological dynamics, especially during the early years or decades after abandonment. In this context, new research topics have arisen: the intensity and frequency of different geomorphological events (Arnáez et al. 1992; Lesschen et al., 2007; Romero-Díaz, et al., 2007; Romero-Díaz, 2016), the estimate of runoff and erosion rates, hydrological functioning of slopes (Gallart, et al., 2002; García-Ruiz and Lana-Renault, 2011; Lana-Renault, et al., 2014; Romero-Díaz et al., 2017), drainage network connectivity (Bellin et al., 2009, Latocha, 2014), carbon redistribution by erosion processes (Boix-Fayos et al., 2017), and plant recolonization and its impact on erosion and soil quality (Benjamin et al., 2005; Pueyo and Beguería, 2007; Van Hall et al., 2017).

Terraced slopes are one of the most common agricultural landscapes in the hilly and mountainous regions throughout the world (Douglas et al., 1994; Tarolli et al., 2014; 
Inbar and Llerena, 2000; Gardner and Gerrard, 2003; Cao et al., 2013; Arnáez et al., 2015). Built in order to ensure agricultural production in the long term, they also helped to reduce the risk of erosion in regions affected by high intensity rainfalls. If farming terraces are well-designed (a flat area enclosed by a riser, and protected by a dry-stone wall), the high infiltration rates of deep soils help to control the surface runoff, sediment production and hydrological connectivity (Gallart et al., 1994; Cammeraat, 2004; Nunes et al., 2016). Traditionally, terraces have acted as an effective soil conservation system at slope or catchment scale (Bevan and Conolly, 2011).

Demographic and socioeconomic changes in the last sixty years in the Mediterranean mountains have led to the abandonment of terraces, with the consequent disappearance of maintenance work required by these agricultural structures, a fact that has facilitated the rise of diverse erosion processes, in particular the collapse of stone walls and small slides triggered in farming terrace risers (Shresta et al., 2004). These erosion processes start to become important after 12-15 years of abandonment and leave the terrace riser completely unprotected and bare, making it one of the main causes of soil degradation on terraced hillsides (Freppaz et al., 2008) and leading to severe environmental and socioeconomic impacts downstream (Douglas et al., 1994; García-Ruiz and López Bermúdez, 2009). Moreover, the collapse of walls and encroachment of shrubland jeopardize conservation of the most fertile soils in mountain areas, and entail the loss of a cultural landscape that is an essential resource for the mountain economy. It came as no surprise that public and private initiatives intended for conserving terraced slopes have been established recently (Asíns, 2009; Lasanta et al., 2013).

In this paper, these mass movements in the upper valleys of Leza, Jubera and Cidacos (Camero Viejo, Iberian Range, Spain) are analysed, by quantifying their size, calculating the probabilities of a certain size to be repeated, and defining the variables involved in their onset. The information can be useful to find out the main sectors prone to soil erosion and thus be able to preserve them more efficiently.

\section{Study area}

The upper valleys of Leza, Jubera and Cidacos (Camero Viejo, Iberian Range, Spain) cover an area of $557.5 \mathrm{Km}^{2}$ (Fig. 1). This mountain range does not have sharp topographical contrasts in the summits and only a small number of peaks are above 1700 $\mathrm{m}$ a.s.l. The steep slopes are located close to rivers and ravines as well as limestone reliefs. The predominant materials (quartzitic sandstones, limestone and conglomerates) correspond to a continental fluvial or lake sedimentation in a subsidence basin (Weald facies). The typical relief shows a succession of anticlines and synclines.

January is the coldest month $\left(3.6^{\circ} \mathrm{C}\right)$ in the study area. The average temperature does not exceed $10^{\circ} \mathrm{C}$ in six consecutive months (from November to April) and daily minimum temperatures can easily fall below $0^{\circ} \mathrm{C}$. August is the warmest month, with average temperatures below $20^{\circ} \mathrm{C}$. Precipitation ranges between 500 and $600 \mathrm{~mm}$ per year. Spring months are the rainiest (32-33\% of annual rainfall). Winter and summer are dry seasons. 


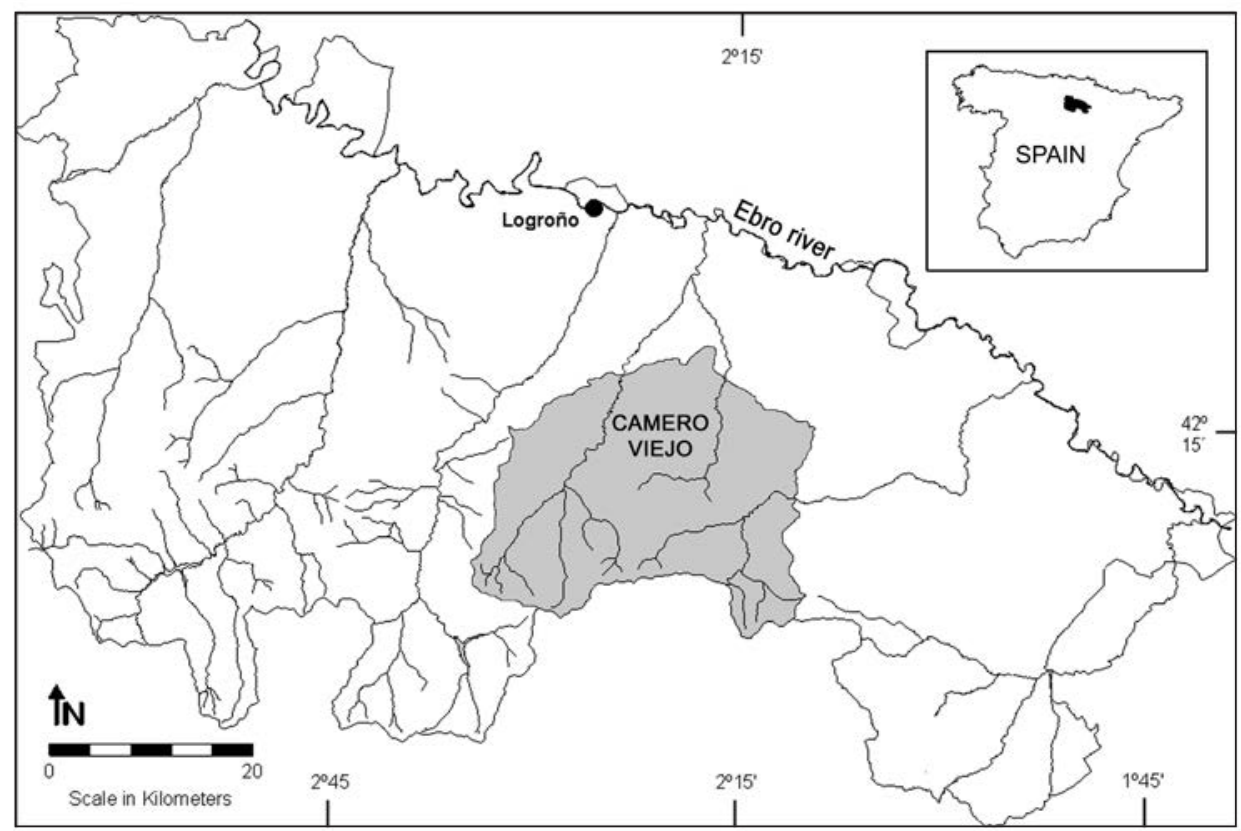

Figure 1. Location of the study area in La Rioja, Spain.

In the upper valleys of Leza, Jubera and Cidacos, oak (Quercus pyrenaica) or beech (Fagus sylvatica) forests became relegated to the headwaters of rivers and ravines, although they have spread again significantly since the mid-twentieth century. However, the greater part of the territory is covered by shrubland: Cistus laurifolius on siliceous soils and Genista scorpius on calcareous soils (Arnáez et al., 2008). At present, a large surface of the study area is occupied by abandoned agricultural fields (Arnáez et al., 2011).

Human pressure on the study area was intense between the $19^{\text {th }}$ century and the beginning of the $20^{\text {th }}$ century. An extensive population decline started in the second half of the $20^{\text {th }}$ century. Rural depopulation became almost absolute in just two decades, giving rise to population densities below 4 inhabitants per $\mathrm{Km}^{2}$. In 1956, 21 ,021 hectares were cultivated ( $38 \%$ of the territory). This surface might have been larger, since some hillslopes were plowed as temporary fields at the end of the $19^{\text {th }}$ century. Agricultural terraces occupied 13,274 hectares of the study area, that is to say $63 \%$ of the agricultural land (Ruiz- Flaño et al., 2009).

\section{Methods}

Fifty-three terraced fields with slides on the walls were selected from aerial photography with a random sampling. Information on the general characteristics of the slope (altitude, exposure, gradient and vegetation cover), the terraced plot (location on the hillside, gradient, length and width, total surface of the field, vegetation cover and stoniness), and the terrace riser (height of the rise, length of the wall, height of the wall built and building materials) were recorded on each field. 
In order to determine the sizes, distribution and recurrence of mass movements on the terrace riser, as well as their relationships with different variables, quantification of their volume was carried out, based on the width, length and depth. This value was associated with different variables of the slope and terrace from correlation coefficients.

The probability of a certain volume mass movement being equaled or exceeded was calculated using recurrence interval calculation. This technique is widely used in hydrology to evaluate the return periods of different floods, or in climatology to study particular rainfall intensity (Haigh, 1984).

The analysis of soil infiltration was carried out from 37 rain simulations of 45 minutes duration. The simulator used was described in detail in Arnáez et al. (2007). It consists of a metal structure shaped like a truncated pyramid with telescopic legs. This allows the simulator to adapt to the terrain features: gradient and soil roughness. The structure has a plastic cover to protect the experiments against wind.

The simulator used various nozzles to reproduce different rainfall intensities: Lechler 460.728 and 406.608 for low and moderate intensities $\left(<70 \mathrm{~mm} \mathrm{~h}^{-1}\right)$ and Lechler 460.880 for high intensities $\left(>70 \mathrm{~mm} \mathrm{~h}^{-1}\right)$. Rainfalls simulated ranged from 37 and $140 \mathrm{~mm} \mathrm{~h}^{-1}$ for a period of $30 \mathrm{~min}$. The nozzles were installed at the top of the metal structure, at 2.5 meters above the ground surface, and connected through a rubber pipe to a pump (Betolini, maximum pressure 20 bar, $17 \mathrm{l} \mathrm{m}^{-1}$ ), a mobile motor (Honda G100) and a 701 water tank. The nozzle produced a homogenous distribution of simulated rainfall on to an area defined by a steel ring $0.45 \mathrm{~m}$ in diameter, with kinetic energy ranging between 340 and $2100 \mathrm{~J} \mathrm{~m}^{-2} \mathrm{~h}^{-1}$ (Navas et al., 1990; Martínez Mena et al., 2001). The metal ring had an outlet to capture runoff at intervals of 3-5 minutes. The outlet was designed with a small pipe located downslope in the plot, so that water and sediment could be collected. Total precipitation generated by the simulator was controlled by three pluviometers located on plot borders. They collected the artificial rain at $10 \mathrm{~min}$ intervals during the experiments.

Information on the following parameters was collected in the simulation tests: rainfall intensity in $\mathrm{mm} \mathrm{h}^{-1}$, runoff in $\mathrm{mm} \mathrm{h}^{-1}$, runoff coefficient (\%) and micro-topography and soil surface features. The average infiltration rate (average volume of water penetrating the ground during the test, in $\mathrm{mm} \mathrm{h}^{-1}$ ) and infiltration coefficient (percentage of precipitation that infiltrates) were calculated from the previous parameters. The infiltration behavior in time (every 5 minutes) was also obtained. Logarithmic curve adjustment $(\mathrm{y}=-b \log X+a)$ or potential $\left(\mathrm{y}=a X^{-b}\right)$, with high $\mathrm{r}^{2}$ value, enabled functioning patterns of the rate and infiltration coefficient for each simulation to be designed, as well as for three groups of rainfall intensity: $<70 \mathrm{~mm} \mathrm{~h}^{-1}, 70-100 \mathrm{~mm} \mathrm{~h}^{-1},>100 \mathrm{~mm} \mathrm{~h}^{-1}$.

Soil samples from topsoil $(0-30 \mathrm{~cm})$, which were analysed in the Regional Laboratory of La Rioja Government, were collected in the tests. Ph, phosphorus (ppm), calcium (meq/100 g of soil), potassium (meq/100 g of soil), magnesium (meq/100 g of soil) and organic matter (\%) were measured in each sample. Soil texture was analysed according to USDA classification. Soil moisture at 5-6\% was measured before the tests.

The data obtained in the simulations were associated with the features of abandoned terraces and slides. 


\section{Results}

Agricultural terraces sampled have an average surface of $727 \mathrm{~m}^{2}$. Only $18 \%$ extend over $1000 \mathrm{~m}^{2}$ or more. However, as the standard deviation shows, variability is high (Table 1). The stone wall protecting the riser is the most characteristic feature of a terraced field (Fig. 2). The average height, according to the sampling carried out, is $1.7 \mathrm{~m}$, although in some cases this reaches $4 \mathrm{~m}$, and it is made of blocks or boulders of quartzitic sandstones, sandstones and limestones of different size (long axis 12-85 cm). The average length of the wall is $54.2 \mathrm{~m}$. In most cases, it coincides with the length of the riser.

Table 1. Terrace characteristics.

\begin{tabular}{lcccc}
\hline & Mean & Maximum & Minimum & St. Dev. \\
\hline Altitude (m. a.s.1.) & 931.5 & 1180 & 700 & 122 \\
Plot surface $\left(\mathrm{m}^{2}\right)$ & 727 & 5000 & 45 & 1006 \\
Terrace wall height (m) & 1.7 & 3.9 & 0.8 & 0.63 \\
Terrace wall length (m) & 54.2 & 200 & 10 & 38.5 \\
\hline
\end{tabular}

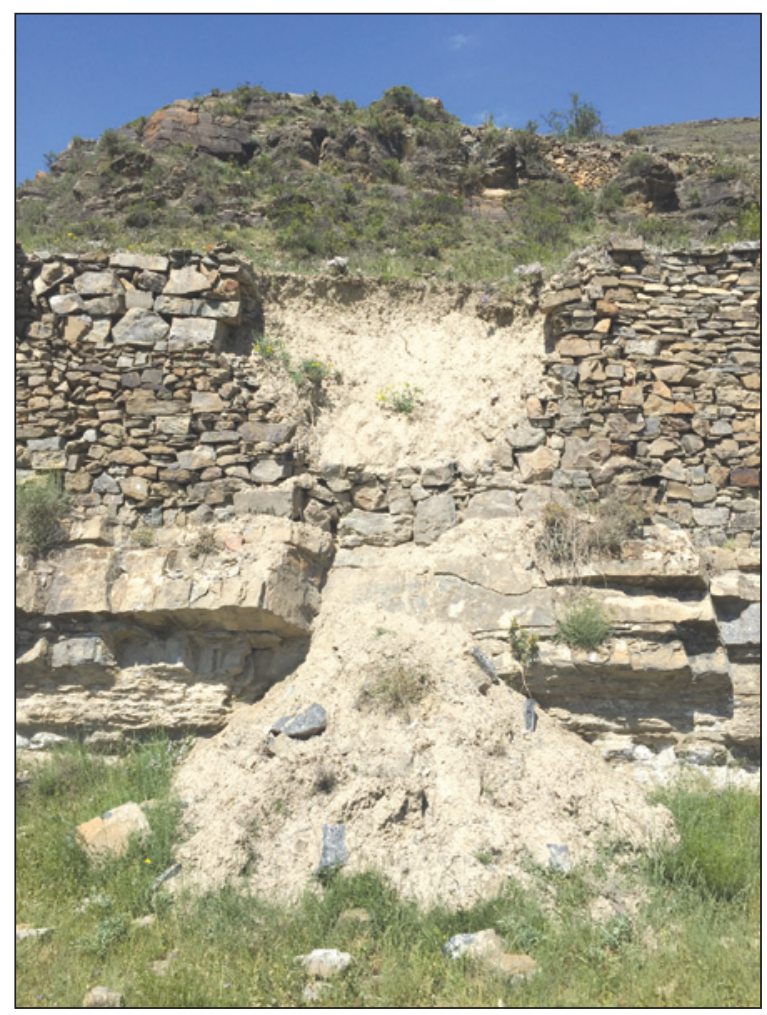

Figure 2. Slide on the terrace wall (Cidacos Valley). 
The most common erosion processes on the walls of abandoned terraces are stone collapses, which leave the riser completely unprotected, and small slides, which not only cause stones to fall from the wall, but also move material from the plot. The slides usually have a high gradient in the upper section and are concave in shape. The displaced material, including stones from the wall, can be seen at the foot of the slide (Fig. 2). In the study area, an average $48 \%$ of the terrace wall has undergone some degree of erosion: stone collapses represent $24.9 \%$ of the total length of stone walls and slides represent $22.6 \%$ (Table 2).

Table 2. Distribution of erosion processes on terraces walls.

\begin{tabular}{lcccc}
\hline & Mean & Maximum & Minimum & St. Dev. \\
\hline Terrace wall with stone falls & $24.9 \%$ & $82.4 \%$ & $0 \%$ & 25 \\
Terrace wall with slides & $22.6 \%$ & $70.0 \%$ & $0 \%$ & 17 \\
\hline
\end{tabular}

A total amount of 240 slides were counted on the 53 plots studied, which means an average number of 4.5 slides per plot and 10.6 per $100 \mathrm{~m}$ of wall. With regard to the volume mobilized, variability is outstanding, so slides smaller than $1 \mathrm{~m}^{3}$ and others bigger than $15 \mathrm{~m}^{3}$ could be found. The average volume of material falling per slide was $3.5 \mathrm{~m}^{3}$ of soil. At plot scale, the average volume of debris was $15.1 \mathrm{~m}^{3}$ and, taking into account the length of the terrace wall, the volume of debris for every $100 \mathrm{~m}$ of wall reached $33.1 \mathrm{~m}^{3}$ (Table 3).

Table 3. Number and size of slides.

\begin{tabular}{lcccc}
\hline & Mean & Maximum & Minimum & St. Dev. \\
\hline Number of slides per plot & 4.5 & 16 & 1 & 3.1 \\
Number of slides per 100 m of wall & 10.6 & 28 & 1.1 & 7.0 \\
Volume mobilized per slide $\left(\mathrm{m}^{3}\right)$ & 3.5 & 15.9 & 0.12 & 3.2 \\
Volume mobilized per plot $\left(\mathrm{m}^{3}\right)$ & 15.1 & 51.5 & 0.12 & 14.3 \\
Volume mobilized per 100 $\mathrm{m}_{\text {of }}$ wall $\left(\mathrm{m}^{3}\right)$ & 33.1 & 156 & 0.47 & 34.6 \\
\hline
\end{tabular}

Recurrence interval calculation, mentioned above in methods, was used to obtain results on the probability of a certain volume mass movement being equaled or exceeded in the terraces studied. Figure 3 includes the equations for calculating the probability of mobilization of a certain volume of material at different scales, and Table 4 shows the results. There is a $75 \%$ chance of mass movements being activated on terrace walls and bringing down a volume of at least $1.1 \mathrm{~m}^{3}\left(7.1 \mathrm{~m}^{3}\right.$ per $100 \mathrm{~m}$ of wall), and a $5 \%$ chance that these will move a volume of $10.9 \mathrm{~m}^{3}$ per slide $\left(111.3 \mathrm{~m}^{3}\right.$ per $100 \mathrm{~m}$ of wall) or more. 

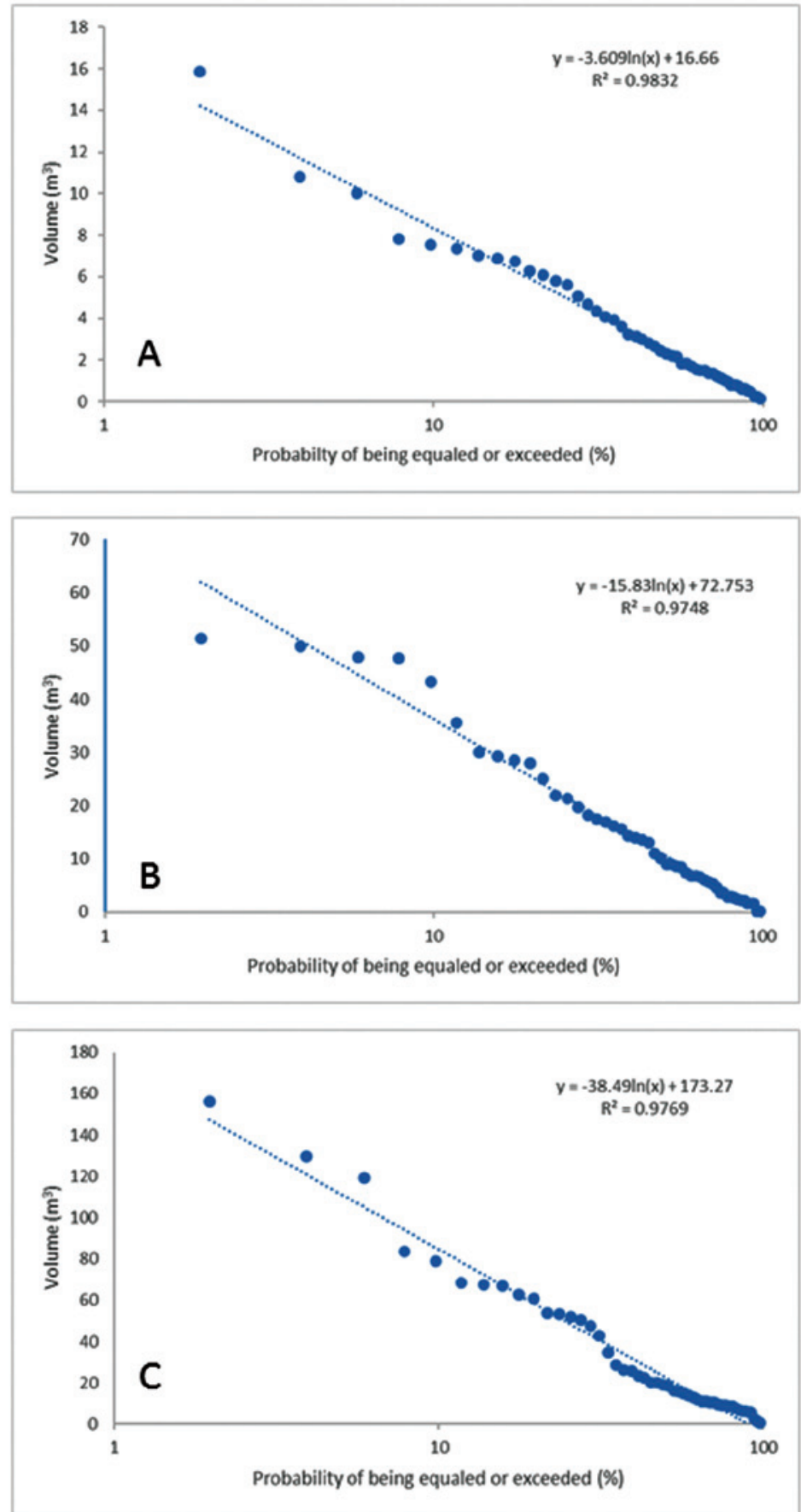

Figure 3. Probability of a certain volume of material being equaled or exceeded

(A: volume per slide; $B$ : volume per plot; $C$ : volume per $100 \mathrm{~m}$ of wall). 
Table 4. Probability of a slide equal to or exceeding a certain volume.

\begin{tabular}{cccc} 
Probability $(\%)$ & $\begin{array}{c}\text { Volume }\left(\mathbf{m}^{3}\right) \text { per } \\
\text { slide }\end{array}$ & $\begin{array}{c}\text { Volume }\left(\mathbf{m}^{3}\right) \text { per } \\
\text { plot }\end{array}$ & $\begin{array}{c}\text { Volume }\left(\mathbf{m}^{3}\right) \text { per } \\
\mathbf{1 0 0} \mathbf{~ m} \text { of wall }\end{array}$ \\
\hline 75 & $\geq 1.1$ & $\geq 4.4$ & $\geq 7.1$ \\
50 & $\geq 2.5$ & $\geq 10.8$ & $\geq 22.7$ \\
25 & $\geq 5$ & $\geq 21.8$ & $\geq 49.4$ \\
10 & $\geq 8.3$ & $\geq 36.3$ & $\geq 84.6$ \\
5 & $\geq 10.9$ & $\geq 47.2$ & $\geq 111.3$ \\
\hline
\end{tabular}

The volume of fallen material was associated to different variables of the slope and the terrace (Table 5). Results show a link between the slope gradient, the size of the plot, the height of the wall and the terrace gradient. As the slope tilts, built terraces are narrower (-0.476), with a steeper slope on the level soil (0.671) and a higher wall (0.346). The height of the wall is positively and significantly correlated to the volume of the mass movements ( 0.659 for the volume detached per plot, 0.340 for the volume detached per $100 \mathrm{~m}$ of wall).

Table 5. Correlations between the slide volumes and different variables.

\begin{tabular}{|c|c|c|c|c|c|c|c|c|c|}
\hline & $\mathbf{S}$ & $\mathbf{W}_{\mathbf{t}}$ & $\mathbf{H}_{\mathbf{t}}$ & $\mathbf{S}_{\mathbf{t}}$ & $\mathbf{V}_{\text {shrub }}$ & $\mathbf{V}_{\text {herb }}$ & $\mathbf{B}_{\mathbf{s}}$ & $\mathbf{Q}_{\mathbf{t}}$ & $\mathbf{Q}_{\mathbf{1 0 0}}$ \\
\hline $\mathrm{S}$ & 1 & $-0.476^{* *}$ & $0.346^{*}$ & $0.671^{*}$ & 0.225 & -0.174 & 0.218 & 0.237 & -0.002 \\
\hline $\mathrm{W}_{\mathrm{t}}$ & & 1 & 0.035 & -0.208 & $-0.371^{* *}$ & 0.268 & -0.232 & 0.172 & 0.193 \\
\hline $\mathrm{H}_{\mathrm{t}}$ & & & 1 & 0.023 & -0.178 & 0.196 & -0.079 & $0.659 * *$ & $0.340^{*}$ \\
\hline $\mathrm{S}_{\mathrm{t}}$ & & & & 1 & 0.181 & 0.068 & -0.047 & -0.035 & -0.068 \\
\hline $\mathrm{V}_{\text {shrub }}$ & & & & & 1 & -0.089 & -0.098 & -0.216 & -0.049 \\
\hline $\mathrm{V}_{\text {herb }}$ & & & & & & 1 & $-0.818^{* *}$ & 0.238 & 0.152 \\
\hline $\mathrm{B}_{\mathrm{s}}$ & & & & & & & 1 & -0.068 & -0.047 \\
\hline $\mathrm{Q}_{\mathrm{t}}$ & & & & & & & & 1 & $0.676^{* *}$ \\
\hline $\mathrm{Q}_{100}$ & & & & & & & & & 1 \\
\hline
\end{tabular}

$\mathrm{S}=$ Slope gradient; $\mathrm{W}_{\mathrm{t}}=$ Width of the terraced field; $\mathrm{H}_{\mathrm{t}}=$ Height of the terrace wall; $\mathrm{S}_{\mathrm{t}}=$ Terrace slope gradient; $\mathrm{V}_{\text {shrub }}=$ Percentage of shrub cover; $\mathrm{V}_{\text {herb }}=$ Percentage of herbaceous cover; $\mathrm{B}_{\mathrm{s}}=$ Bare ground; $\mathrm{Q}_{\mathrm{t}}=$ Volume mobilized per plot; $\mathrm{Q}_{100}=$ Volume mobilized per $100 \mathrm{~m}$ of wall.

** Correlation is significant in level 0.01 .

* Correlation is significant in level 0.05 .

Soil infiltration capacity and the way in which water runs down the hillside may be the main triggers for slides, (Gallart et al., 1994; Zgaier and Inbar, 2005). High infiltration is expected in plots with little gradient, where soils have been accumulated 
and redistributed by the farmer, and silt loam texture. The results of the physical and chemical properties in the topsoils are included in Table 6 . The average content of organic matter is $2.7 \%$, although the coefficient of variation is very high (above 53\%). Textural properties have average sand values of $22.4 \%$, silts of $60.9 \%$ and clays of $16.6 \%$. Cerdà (1995) points out that organic matter is shown as a positive feature for soil infiltrability and that this is very high, with values of $2-3 \%$.

Table 6. Physical and chemical soil properties.

\begin{tabular}{lcccccccccc} 
& pH & $\mathbf{P}$ & $\mathbf{C a}$ & $\mathbf{K}$ & $\mathbf{M g}$ & $\begin{array}{c}\text { OM } \\
(\boldsymbol{\%})\end{array}$ & $\begin{array}{c}\text { Sand } \\
(\boldsymbol{\%})\end{array}$ & $\begin{array}{c}\text { Silt } \\
(\boldsymbol{\%})\end{array}$ & $\begin{array}{c}\text { Clay } \\
(\boldsymbol{\%})\end{array}$ & Texture \\
\hline mean & 7.7 & 229.3 & 17.7 & 0.58 & 0.91 & 2.7 & 22.4 & 60.9 & 16.6 & Silt loam soil \\
$\mathrm{CV}(\%)$ & 2.3 & 50.3 & 21.7 & 46.5 & 50.9 & 39.3 & 41 & 16.1 & 26.5 & \\
\hline
\end{tabular}

Units for $\mathrm{P}, \mathrm{Ca}, \mathrm{K}$ and $\mathrm{Mg}$ are meq/100 of soil.

Simulations carried out on these soils show an average infiltration coefficient above $75 \%$ in the three groups of precipitation intensity $\left(<70 \mathrm{~mm} \mathrm{~h}^{-1} ; 70-100 \mathrm{~mm} \mathrm{~h}^{-1}\right.$ and $>$ $100 \mathrm{~mm} \mathrm{~h}^{-1}$ ) (Table 7). Note that, in Fig. 4, infiltration is very high during the first few minutes of the experiment, with infiltration coefficients above $80 \%$ during the first 5 minutes. It also confirmed that infiltration coefficient and infiltration rates are always higher with less intense rainfall (below $70 \mathrm{~mm} \mathrm{~h}^{-1}$ ). On the contrary, with precipitation above $100 \mathrm{~mm} \mathrm{~h}^{-1}$ infiltration values, not surprisingly, reduce to give way to a higher percentage of surface runoff.

Table 7. Results of infiltration values obtained from rain simulations.

\begin{tabular}{|c|c|c|c|c|c|c|}
\hline & \multicolumn{2}{|c|}{$\begin{array}{l}<70 \mathrm{~mm} \mathrm{~h}^{-1} \\
\mathrm{~N}^{0} \text { cases: } 6\end{array}$} & \multicolumn{2}{|c|}{$\begin{array}{l}70-100 \mathrm{~mm} \mathrm{~h}^{-1} \\
\mathrm{~N}^{0} \text { cases: } 17\end{array}$} & \multicolumn{2}{|c|}{$\begin{array}{l}>100 \mathrm{~mm} \mathrm{~h}^{-1} \\
\mathrm{~N}^{0} \text { cases: } 14\end{array}$} \\
\hline & Media & St. Dev. & Media & St. Dev & Media & St. Dev. \\
\hline $\operatorname{Ip}\left(\mathrm{mm} \mathrm{h}^{-1}\right)$ & 52 & 12.3 & 82.6 & 8.1 & 113.8 & 12.2 \\
\hline $\operatorname{Tim}\left(\mathrm{mm} \mathrm{h}^{-1}\right)$ & 44.8 & 17.9 & 64.1 & 18.9 & 85.6 & 27.8 \\
\hline $\operatorname{Tin}\left(\mathrm{mm} \mathrm{h}^{-1}\right)$ & 52.0 & 12.3 & 77.3 & 8.6 & 99.6 & 19.1 \\
\hline $\operatorname{Cim}(\%)$ & 85.1 & 23.1 & 76.6 & 20 & 75.7 & 20.2 \\
\hline Cin $(\%)$ & 100 & & 93.5 & 8.7 & 87.5 & 14.5 \\
\hline
\end{tabular}

Ip: Precipitation intensity in 30 minutes; Tim: Average infiltration rate during the experiment; Tin: Average rate of initial infiltration (minute 5); Cim: Average infiltration coefficient during the experiment; Cin: Average rate of initial infiltration coefficient (minute 5).

Once the water has infiltrated, it becomes a destabilizing element for the terrace wall. This becomes worse if taking into account the inability of water to percolate in depth when meeting the original soil of the slope or a more impermeable substrate. Under these conditions water tends to accumulate behind the stone wall. The increase 
in weight of the material, in addition to the riser slope, promote the activation of slides, which is why larger volumes of debris are on the slope sectors receiving a higher quantity of water. As is shown in Table 8 and Fig. 5, the volumes of debris are greater on concave hillsides (18.8 $\mathrm{m}^{3}$ volume per plot and $47.6 \mathrm{~m}^{3}$ volume per $100 \mathrm{~m}$ of wall), although the differences are not significant. Infiltration coefficients are also higher on concave hillsides (above 85\%), probably because the plots in these sectors were tilled intensively in the past, with plowed and permeable anthropogenic soils. This was less certain when the number of slides was studied, with straight hillsides found to have the highest values.
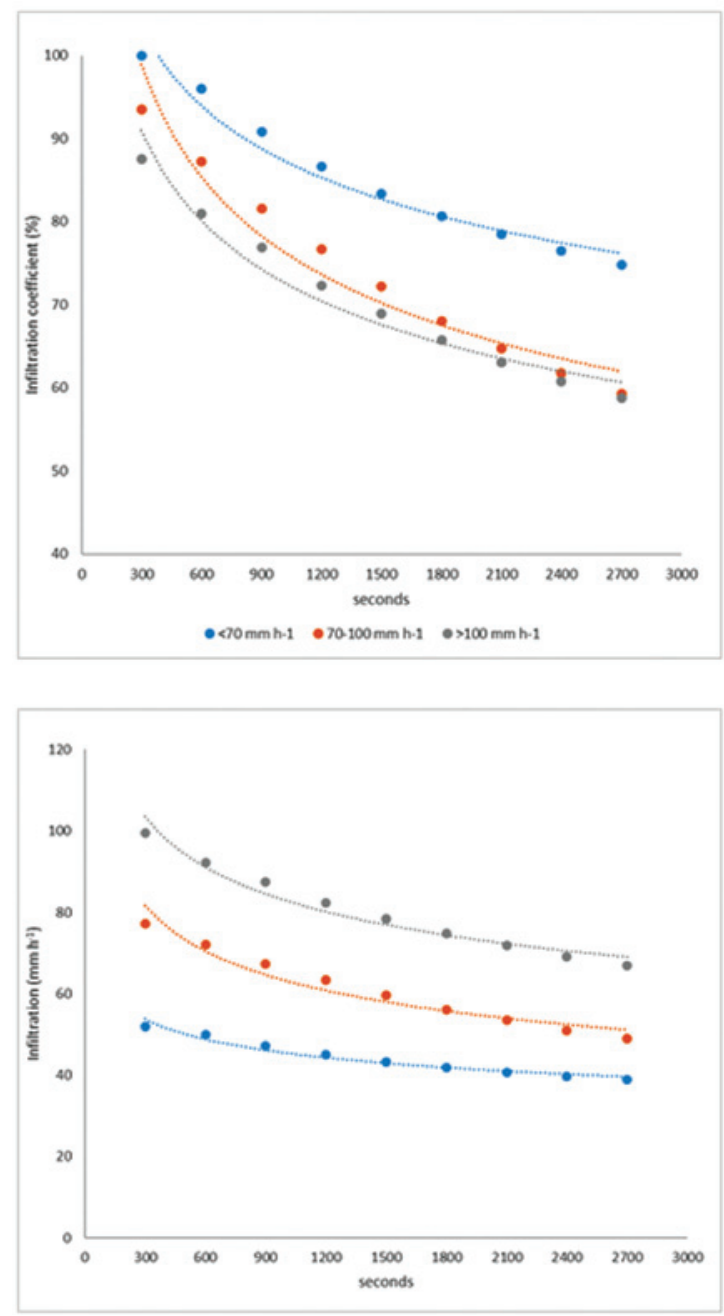

Figure 4. Coefficients and infiltration rates for different rainfall intensities. Infiltration coefficient (Ip $<70 \mathrm{~mm} \mathrm{~h}^{-1}: y=228.24 x^{-0.139}, r^{2}=0.96$; Ip 70-100 $\mathrm{mm} \mathrm{h}^{-1}: y=333.34 x^{-0.213}, r^{2}=0.94 ;$ Ip $>100$ $\left.m m h^{-1}: y=260.7 x^{-0.185}, r^{2}=0.96\right)$. Infiltration rates $\left(I p<70 \mathrm{~mm} \mathrm{~h} h^{-1}: y=118.8 x_{-}^{-0.139}, r^{2}=0.96 ; 70\right.$ $\left.100 \mathrm{~mm} \mathrm{~h}^{-1}: y=275.77 x^{-0.213}, r^{2}=0.94 ; \mathrm{Ip}>100 \mathrm{~mm} \mathrm{~h}^{-1}: y=296.52 x^{-0.184}, r^{2}=0.96\right)$. 
Table 8. Means of the number and volumes of slides and infiltration coefficients, depending on the location of the farming terrace on the hillside.

\begin{tabular}{|c|c|c|c|c|}
\hline & $\begin{array}{c}\text { Convex } \\
\text { slope }\end{array}$ & $\begin{array}{c}\text { Straight } \\
\text { slope }\end{array}$ & $\begin{array}{c}\text { Concave } \\
\text { slope }\end{array}$ & $\begin{array}{l}\text { Anova } \\
\text { Sig. }\end{array}$ \\
\hline Slope gradient & $18.1^{\mathrm{a}}$ & $22.8^{\mathrm{b}}$ & $17.3^{\mathrm{a}}$ & 0.015 \\
\hline Number of slides per plot & $3.95^{\mathrm{a}}$ & $6.79^{\mathrm{b}}$ & $4.12^{\mathrm{a}}$ & 0.012 \\
\hline Number of slides per $100 \mathrm{~m}$ of wall & $10^{\mathrm{a}}$ & $12.1^{\mathrm{a}}$ & $10^{\mathrm{a}}$ & 0.638 \\
\hline Average volume per plot $\left(\mathrm{m}^{3}\right)$ & $11.4^{\mathrm{a}}$ & $15.3^{\mathrm{a}}$ & $18.8^{\mathrm{a}}$ & 0.311 \\
\hline Volume of slide per $100 \mathrm{~m}$ of terrace $\left(\mathrm{m}^{3}\right)$ & $28.6^{\mathrm{a}}$ & $21.3^{\mathrm{a}}$ & $47.6^{\mathrm{a}}$ & 0.083 \\
\hline Infiltration coefficient $<70 \mathrm{~mm} \mathrm{~h}^{-1}(\%)$ & 77.7 & & 88.7 & 0.640 \\
\hline Infiltration coefficient $70-100 \mathrm{~mm} \mathrm{~h}^{-1}(\%)$ & $72.7^{\mathrm{a}}$ & $78.3^{\mathrm{a}}$ & $77.7^{\mathrm{a}}$ & 0.917 \\
\hline Infiltration coefficient $>70 \mathrm{~mm} \mathrm{~h}^{-1}(\%)$ & $69.6^{\mathrm{a}}$ & $69.1^{\mathrm{a}}$ & $79.1^{\mathrm{a}}$ & 0.725 \\
\hline
\end{tabular}

Means with the same letter in the same row are not significantly different at 0.05 level (Bonferroni test).
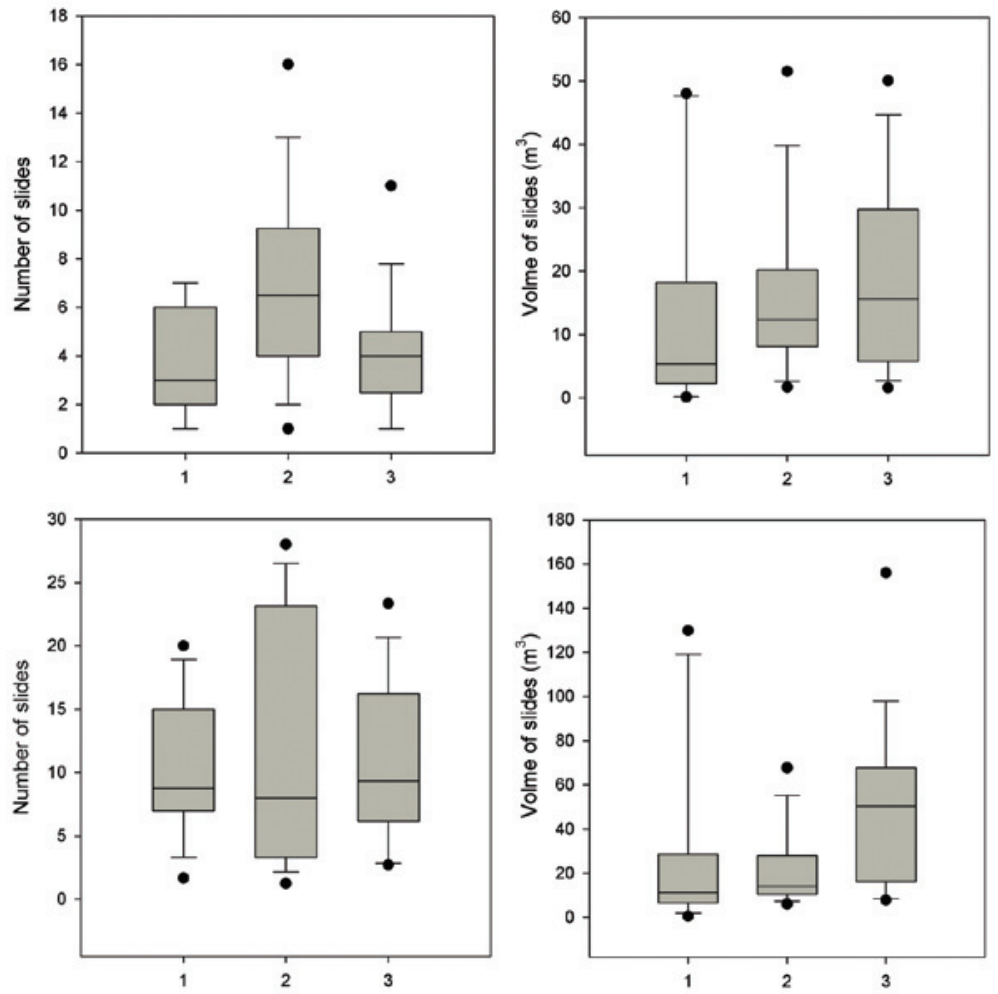

Figure 5. Number and volume of terrace failures according to their position on the slope (1: convex; 2: straight; 3: concave) per plot (up) and per $100 \mathrm{~m}$ of terrace wall (bottom) (median value, 1 st and 3 rd quartiles, 1 st and 9th deciles). 


\section{Discussion}

Mediterranean mountain areas have undergone significant changes in the last few decades because of population decline and agricultural abandonment (MacDonald et al., 2000; García-Ruiz and Lana-Renault, 2011). Ancient slopes cultivated as terraces have been abandoned, thus creating new environmental dynamics. Some have been recolonized by natural vegetation, which, depending on the time of abandonment, are at different stages in the vegetation succession as well as a different percentage of coverage (Chauchard et al., 2007; Lasanta et al., 2015). Others, on the contrary, are affected by the acceleration of erosive and hydrological processes. In the case of farming terraces, the walls are structures requiring regular maintenance to continue acting as retainers of water and soil (Costra et al., 2003). Lack of this work may give rise to small mass movements. The result is an increase in geomorphological risk with several instability problems and an increase in the rates of sediment carried towards the drainage network (Brancucci and Paliaga (2006). Koulouri and Giourga (2007) point out that soil erosion spreads significantly on terraces planted with olive trees following abandonment, due to the collapse of dry stone walls and sparse vegetation cover.

At the beginning of the $20^{\text {th }}$ century, the upper valleys of Leza, Jubera and Cidacos rivers, in the western Iberian Range (Spain), held more than 10,000 inhabitants and a cultivated area of 21,021 hectares, of which 13,274 hectares were farming terraces (63\% of agricultural area). Erosion of these terraces was found to be conditioned by the hydrological functioning of the slope, characterized by the prevalence of high infiltration rates (infiltration coefficients above $75 \%$ ) and by the subsurface runoff on soils with very permeable horizons, tilled by agricultural work and lying on a substrate of quartzitic sandstones and sandstones. It assists in accumulating water in the soil and the circulation of subsurface runoff. This fact explains that the most noticeable processes on farming terraces are small slides located in the riser, affecting the stone wall and also the section of soil in the plot just behind the wall. Specifically, in the study area, slides dismantle $22.6 \%$ of the length of stone walls, calculated at an average mobilization of $33.1 \mathrm{~m}^{3}$ of material per $100 \mathrm{~m}$ of wall. As they are activated by the weight from relatively deep soil, capable of absorbing water coming from rainfall or from the upper areas of the slope, it is therefore not surprising that the higher concentration of mass movements has been found on concave slopes. Lesschen et al. (2008) state that abandoned terraced slopes on steep hillsides, with loamy soils located at the foot of slopes and valley bottoms unite the best conditions for increasing the risk of breakage, in addition to terrace wall slides.

However, at slope or catchment scale, terracing of slopes proves to be a useful system of soil conservation. Water retention from infiltration and the reduction of the slope compensates the activity of surface runoff. Pelotto and D'Angelo (in press) applied the FLO-2D model to a terraced basin in Italy, testing to find out whether an increase in the terraced surface reduced runoff, and using a logarithmic function (for example, an increase in the terraced area from $10 \%$ to $30 \%$ could lead to a reduction of peak runoff of about $45 \%$ ). 
Furthermore, the trend towards stability rises as plots are occupied by vegetation. Research on experimental terraced catchments showed that sediment production is low (Lal, 1982; Llorens et al., 1992; Zhang and Li, 2014). Gallart and Llorens (1994) state that fallen walls and slides, despite their spectacular nature, do not seem to raise significant concerns in most cases. This is partly because of the poor connectivity which usually occurs between the slopes and the channels in terraced environments and which, in most cases, is reduced due to an increase in vegetation following agricultural abandonment (López-Vicente et al., 2015, 2016). However, with high intensity precipitation, Brandolini et al. (2016) have verified that landslides on abandoned terraces mobilize large volumes of soil, much higher than those calculated for our area of study. These authors state that maintaining terraces is a good method of mitigating geo-hydrological risks.

\section{Conclusions}

One of the functions of terraces is to reduce runoff; consequently, wall maintenance may be the best way to prevent erosion. However, terraces also contribute to increased soil moisture content through infiltration. Their abandonment involves changes in the distribution of saturated areas and drainage networks, and the possibility of activating small mass movements. In the upper valleys of Leza, Jubera and Cidacos (Iberian Range, Spain), about $50 \%$ of wall terraces has been demolished either by slides or rock falls, with large volumes of debris. These terraces coincide with specific topographic environments and land uses. In particular, concave slopes, where water concentrates and infiltration rates are usually higher, are sensitive to erosion. Thus, the impoverishment of areas essential for the survival of mountain-dwellers is being accelerated.

\section{Acknowledgments}

Support for this research was provided by the project ESPAS (Water and sediment production scenarios on the basis of vegetation and land use changes: effects of active and passive land management) (grant $n^{\circ}$ CGL2015-65569-R) which is funded by MINECO/ FEDER.

\section{References}

Arnáez, J., Ortigosa, L., Oserín, M. 1992. Descripción y cuantificación de procesos erosivos en bancales abandonados (Sistema Ibérico, La Rioja). In: F. López-Bermúdez, C. Conesa, A. Romero-Díaz, Estudios de Geomorfología en España. Sociedad Española de Geomorfología, Murcia, pp. 193-201.

Arnáez, J., Lasanta, T., Ruiz-Flaño, P., Ortigosa, L. 2007. Factors affecting runoff and erosion under simulated rainfall in Mediterranean vineyards. Soil and Tillage Research 93, 324-334. http://doi.org/10.1016/j.still.2006.05.013.

Arnáez, J., Ortigosa, L., Oserín, M., Lasanta, T. 2008. Plant cover and land uses changes in the Northwestern Iberian Range (Los Cameros, La Rioja, Spain) between 1956 and 2001. Boletín de la Asociación de Geógrafos Españoles 47, 401-403. 
Arnáez, J., Lasanta, T., Errea, M.P., Ortigosa, L. 2011. Land abandonment, landscape evolution, and soil erosion in a Spanish Mediterranean mountain: The case of Camero Viejo. Land Degradation \& Development 22, 537-550. http://doi.org/10.1002/ldr.1032.

Arnáez, J., Lana-Renault, N., Lasanta, T., Ruiz-Flaño, P., Castroviejo, J. 2015. Effects of farming terraces on hydrological and geomorphological processes. A review. Catena 128, 122-134. http://doi.org/10.1016/j.catena.2015.01.021.

Bellin, N., van Wesemael, B., Meerkerk, A., Vanacker, V., Barbera, G. G. 2009. Abandonment of soil and water conservation structures in Mediterranean ecosystems. A case study from south east Spain. Catena 76, 114-121. http://doi.org/10.1016/j.catena.2008.10.002.

Benjamin, K., Domon, G., Bouchard, A. 2005. Vegetation composition and succession of abandoned farmland: effects of ecological, historical and spatial factors. Landscape Ecology 20, 627-647. http://doi.org/10.1007/s10980-005-0068-2.

Bevan, A., Conolly, J. 2011. Terraced fields and Mediterranean landscape structure: an analytical case study from Antikythera, Greece. Ecological Modelling 222, 1303-1314. http://doi. org/10.1016/j.ecolmodel.2010.12.016.

Boix-Fayos, C., Martínez-Mena, M., Pérez Cutillas, P., De Vente, J., Barberá, G.G., Mosch, W., Navarro Cano, J.A., Gaspar, L., Navas, A. 2017. Carbon redistribution by erosion processes in an intensively disturbed catchment. Catena 149, 799-809. http://doi.org/10.1016/j. catena.2016.08.003.

Brancucci, G., Paliaga, G. 2006. The hazard assessment in a terraced landscape: preliminary result of the Liguria (Italy) case study in the Interreg III Alpter project. ECI Conference on Geohazards, Paper 16, Lillehammer, Norway.

Brandolini, P., Cevasco, A., Capolongo, D., Pepe, G., Lovergine, F., Del Monte, M. 2016. Response of terraced slopes to a very intense rainfall event and relationships with land abandonment: a case study from Cinque Terre (Italy). Land Degradation \& Development. http://doi.org/10.1002/ldr.2672.

Cammeraat L.H. 2004. Scale dependent thresholds in hydrological and erosion response of a semiarid catchment in southeast Spain. Agriculture, Ecosystems and Environment 104, 317-332. http://doi.org/10.1016/j.agee.2004.01.032.

Cao, Y., Wu, Y., Zhang, Y., Tian, J. 2013. Landscape pattern and sustainability of a 1300-yearold agricultural landscape in subtropical mountain areas, Southwestern China. International Journal of Sustainable Development \& World Ecology 20 (4), 349-357. http://doi.org/10.1080/ 13504509.2013.773266.

Cerdà, A. 1995. Factores y variaciones espacio-temporales de la infiltración en los ecosistemas mediterráneos. Geoforma Ediciones, 151 pp., Logroño.

Chauchard, S., Carcaillet, C., Guibal, F. 2007. Patterns of land-use abandonment control treerecruitment and forest dynamics in Mediterranean mountains. Ecosystems 10, 936-948. http://doi.org/10.1007/s10021-007-9065-4.

Crosta, G.B., Dal Negro, P., Frattini, P. 2003. Soil slips and debris flows on terraced slopes. Natural Hazards and Earth System Sciences 3, 31-42. http://doi.org/10.5194/nhess-3-31-2003.

Douglas, T.D., Kirkby, S.J., Critchley, R.W., Park, G.J. 1994. Agricultural terrace abandonment in the Alpujarra, Andalucía, Spain. Land Degradation \& Development 5, 281-291. http://doi. org/10.1002/ldr.3400050405.

Freppaz, M., Agnelli, A., Drusi, B., Stanchi, S., Galliani, C., Revel Chion, V., Zanini, E. 2008. Soil quality and fertility: studies in the Valle d'Aosta. In: E. Fontanari, D. Patassini (Eds.), Terraced Landscapes of the Alps. Projects in Progress. Marsilio, Venice.

Gallart, F., Llorens, P., Latron, J. 1994. Studying the role of old agricultural terraces on runoff generation in a small Mediterranean mountainous basin. Journal of Hydrology 159, 291-303. http://doi.org/10.1016/0022-1694(94)90262-3. 
Gallart, F., Llorens, P., Latron, J., Regüés, D. 2002. Hydrological processes and their seasonal controls in a small Mediterranean mountain catchment in the Pyrenees. Hydrology and Earth System Sciences 6, 527-537. http://doi.org/10.5194/hess-6-527-2002.

García-Ruiz, J.M., López Bermúdez, F. 2009. La erosión del suelo en España. Sociedad Española de Geomorfología, 441 pp., Zaragoza.

García-Ruiz, J.M., Lana-Renault, N. 2011. Hydrological and erosive consequences of farmland abandonment in Europe, with special reference to the Mediterranean region - A review. Agriculture, Ecosystem and Environment 140, 317-338. http://doi.org/10.1016/j. agee.2011.01.003.

Gardner, R., Gerrard, J. 2003. Runoff and soil erosion on cultivated rainfed terraces in the Middle Hills of Nepal. Applied Geography 23, 23-45. http://doi.org/10.1016/S0143-6228(02)00069-3.

Haigh, M.J. 1984. Landslide prediction and highway maintenance in the Lesser Himalaya, India. Zeitschrift für Geomorphologie, suppl. Bd. 51, 17-37.

Inbar, M., Llerena, C.A. 2000. Erosion processes in high mountain agricultural terraces in Perú. Mountain Research and Development 20, 72-79. http://doi.org/10.1659/02764741(2000)020[0072: EPIHMA]2.0.CO;2.

Koulouri, M., Giourga, C. 2007. Land abandonment and slope gradient as key factors of soil erosion in Mediterranean terraced lands. Catena 69, 274-281. http://doi.org/10.1016/j. catena.2006.07.001.

Lal, R. 1982. Effect of slope length and terracing on runoff and erosion on a tropical soil. In: D. Walling (Ed.), Recent Development in the Explanation and Prediction Erosion and Sediment Yield. IAHS Publication 137, 23-31.

Lana-Renault, N., Regüés, D., Serrano, P., Latron, J. 2014. Spatial and temporal variability of groundwater dynamics in a sub-Mediterranean mountain catchment. Hydrological Processes 28, 3288-3299. http://doi.org/10.1002/hyp.9892.

Lasanta, T. 1990. Diversidad de usos e integración espacial en la gestión tradicional del territorio en las montañas de Europa occidental. In: J.M. García-Ruiz (Ed.), Geoecología de áreas de montaña, Geoforma Ediciones, Logroño, pp. 235-266.

Lasanta, T., Arnáez, J., Ruiz-Flaño, P., Lana-Renault, N. 2013. Agricultural terraces in the Spanish Mountain: an abandoned landscape and a potential resource. Boletín de la Asociación de Geógrafos Españoles 63, 487-491.

Lasanta, T., Nadal-Romero, E., Arnáez, J. 2015. Managing abandoned farmland to control the impact of re-vegetation on the environment. The state of the art in Europe. Environmental Science \& Policy 52, 99-109. http://doi.org/10.1016/ j.envsci.2015.05.012.

Lasanta, T., Arnáez, J., Pascual, N., Ruiz-Flaño, P., Errea, M.P., Lana-Renault, N. 2017. Spacetime process and drivers of land abandonment in Europe. Catena 149, 810-823. http://doi. org/10.1016/j.catena.02.024.

Latocha, A. 2014. Geomorphic connectivity within abandoned small catchments (Stołowe Mts, SW Poland). Geomorphology, 212, 4-15. http://doi.org/10.1016/ j.geomorph.2013.04.030.

Lesschen, J.P., Kok, K., Verburg, P.H., Cammeraat, L.H. 2007. Identification of vulnerable areas for gully erosion under different scenarios of land abandonment in Southeast Spain. Catena, 71, 110-121. http://doi.org/10.1016/j.catena.2006.05.014.

Lesschen, J.P., Cammeraat, L.H., Nieman, T. 2008. Erosion and terrace failure due to agricultural land abandonment in a semi-arid environment. Earth Surface Processes and Landforms 33, 1574-1584. http://doi.org/10.1002/esp.1676.

Llorens, P., Latron, J., Gallart, F. 1992. Analysis of the role of agricultural abandoned terraces on the hydrology and sediment dynamics in a small mountainous basin (High Llobregat, Eastern Pyrenees). Pirineos 139, 27-46. http://doi.org/ 10.3989/pirineos. 1992.v139.180. 
López-Vicente, M., Quijano, L., Palazón, L., Gaspar, L., Navas, A. 2015. Assessment of soil redistribution at catchment scale by coupling a soil erosion model and a sediment connectivity index (central Spanish pre-Pyrenees). Cuadernos de Investigación Geográfica 41(1), 127 147. http://doi.org/10.18172/cig.2649.

López-Vicente, M., Nadal-Romero, E., Cammeraat, E. 2016. Hydrological connectivity does change over 70 years of abandonment and afforestation in the Spanish Pyrenees. Land Degradation \& Development. http://doi.org/10.1002/ldr.2531.

MacDonald, D., Crabtree, J R., Wiesinger, G., Dax, T., Stamou, N., Fleury, P., Gutierrez Lazpita, J., Gibon, A. 2000. Agricultural abandonment in mountain areas of Europe: Environmental consequences and policy response. Journal of Environmental Management 59, 47-69. http:// doi.org/10.1006/jema.1999.0335.

Martínez-Mena, M., Abadía, R., Castillo, V., Albaladejo, J. 2001. Diseño experimental con lluvia simulada para el estudio de los cambios en la erosión del suelo durante la tormenta. Cuaternario y Geomorfología 15, 31-43.

Navas, A., Alberto, F, Machín, J., Galán, J. 1990. Design and operation of a rainfall simulator for field studies of runoff and soil erosion. Soil Technology 3, 385-397. http://doi. org/10.1016/0933-3630(90)90019-Y.

Nunes, A.N.,Coelho, C.O.A., De Almeida,A.C., Figueiredo,A. 2010. Soil erosion and hydrological response to land abandonment in a central inland area of Portugal. Land Degradation \& Development 21, 260-273. http://doi.org/10.1002/ldr.973.

Nunes, J.P., Bernard-Jannin, L., Rodríguez Blanco, M.L., Santos, J.M., de Oliveira Alves Coelho, C., Keizer, J.J. 2016. Hydrological and erosion processes in terraced fields: observations from a humid Mediterranean region in Northern Portugal. Land Degradation \& Development. http://doi.org/10.1002/ldr.2550.

Perlotto, C., D'Agostino, V. in press. Performance assessment of bench terraces through 2-D modelling. Land Degradation \& Development. http://doi.org/10.1002/ldr.2653.

Price, L.W. 1981. Mountains and man. University of California Press, Berkeley and Los Angeles, $506 \mathrm{pp}$.

Pueyo, Y., Beguería, S. 2007. Modelling the rate of secondary succession after farmland abandonment in a Mediterranean mountain area. Landscape and Urban Planning 83, 245 254. http://doi.org/10.1016/j.landurbplan.2007.04.008.

Romero Díaz, A. (Coord.) 2016. Abandono de cultivos en la región de Murcia. Consecuencias ecogeomorfológicas. Editum, Ediciones de la Universidad de Murcia, Murcia, 263 pp.

Romero Díaz, A., Marín Sanleandro, P., Sánchez Soriano, A. Belmonte Serrato, F., Faulkner, H. 2007. The causes of piping in a set of abandoned agricultural terraces in southeast Spain. Catena 69, 282-293. http://doi.org/10.1016/j.catena.2006.07.008.

Romero-Díaz, A., Ruiz-Sinoga, J.D., Robledano-Aymerich. Brevik, E.C., Cerdà, A. 2017. Ecosystem responses to land abandonment in Western Mediterranean mountains. Catena 149, 824-835. http://doi.org/10.1016/j.catena.2016.08.013.

Ruiz-Flaño, P., Lasanta, T., Arnáez, J., Ortigosa, L., Oserín, M. 2009. El proceso de abandono del espacio agrícola en Camero Viejo. En: Gestión, usos del suelo y paisaje en Cameros (Sistema Ibérico, La Rioja). Universidad de La Rioja-Instituto de Estudios Riojanos, Logroño, pp. 101-126.

Shresta, D.P., Zinck, J.A., Van Ranst, E. 2004. Modelling land degradation in the Nepalese Himalaya. Catena 57, 135-156. http://doi.org/10.1016/j.catena.2003.11.003.

Tarolli, P., Preti, F., Romano, N. 2014. Terraced landscape: from an old best practice to a potential hazard for soil degradation due to land abandonment. Anthropocene 6, 10-25. http://doi. org/10.1016/j.ancene.2014.03.002. 
Van Hall, R.L., Cammeraat, L.H., Keesstra, S.D., Zorn, M. 2017. Impact of secondary vegetation succession on soil quality in a humid Mediterranean landscape. Catena 149, 836-843. http:// doi.org/10.1016/j.catena.2016.05.021.

Zgaier, A., Inbar, M. 2005. The influence of soil saturation on the stability of abandoned agricultural hillslope terraces under Mediterranean climatic conditions. Developments in Earth Surface Processes 7, 69-86. http://doi.org/10.1016/S0928-2025(05)80011-2.

Zhang, Q.W., Li, Y. 2014. Effectiveness assessment of soil conservation measures in reducing soil erosion in Baiquan County of Northeastern China by using 137Cs techniques. Environmental Science: Processes \& Impacts 16, 1480-1488. http://doi.org/ 10.1039/C3EM00521F. 